\title{
Assessment of genetic diversity based on principal component analysis in vegetable cowpea (Vigna unguiculata (L.) Walp.) germplasm
}

\author{
Pidigam Saidaiah*, Pandravada Someswar Rao*, Amarapalli Geetha**, Adapa Kiran Kumar and Venkateswaran Kamala* \\ Department of Genetics and Plant Breeding, College of Horticulture, Sri Konda Laxman Telangana State Horticultural University, \\ Mojerla-509 382, Telangana, India \\ * Division of Plant Genetic Resources and Economic Botany, ICAR-National Bureau of Plant Genetic Resources, Regional Station, \\ Rajendranagar-500 030, Hyderabad, Telangana, India
}

** Department of Crop Physiology, College of Agriculture, Professor Jayashankar Telangana State Agricultural University, Palem-509 215, Nagarkurnool District, Telangana, India

\section{Article Info}

Article history

Received 5 May 2021

Revised 22 June 2021

Accepted 23 June 2021

Published online 30 June 2021

\section{Keywords}

Genetic diversity

Germplasm

PCA

Vigna unguiculata (L.) Walp.

Vegetable cowpea

Yield

\begin{abstract}
Data on key flowering, maturity and yield attributes of 87 cowpea accessions including exotic and indigenous accessions were subjected to genotype clustering and principal component analysis (PCA) to identify diverse elite accessions for vegetable purpose. Based on PCA, PC-I, PC-II and PC-III had eigen values more than one, which contributed to $90.87 \%$ of total cumulative variability among germplasm. PC-I followed by PC-II and PC-III contributed maximum $(46.34 \%, 28.40 \%$ and $15.63 \%)$ towards variability. The PC-I exhibited factor loadings in the positive sign for days taken to the happening of first flowering, days required to $50 \%$ of plants to flower, days taken to setting of first fruit and days to first harvest, while, except pods per plant and per plant pod yield, all other factors registered were positive towards PC-II. As many as nine traits have contributed positive factor loadings towards PC-III. Cluster analysis grouped 87 vegetable cowpea genotypes into 16 divergent clusters, cluster-II comprised a maximum of 45 genotypes followed by cluster I and XII. As many as 10 out of 16 clusters were solitary with unique genotypes revealing a greater amount of diversity among the germplasm. As confirmed by the $\mathrm{D}^{2}$ statistic, the maximum diversity was elucidated by the VI cluster genotypes against those of cluster-XVI and between clusters VII and XVI as well. The maximum uniformity was observed between cluster-IV and cluster-V. Selection of genotypes should be based on the pods formed per plant followed by days taken to $50 \%$ flowering of plants, as their contribution for the total divergence of the germplasm was the maximum. Therefore, the investigation suggests that cross combinations between divergent accessions of cluster-V, III, and II, may lead to maximum heterosis in realizing hybrid breeding and isolation of superior breeding lines as well in vegetable cowpea breeding.
\end{abstract}

\section{Introduction}

Cowpea (Vigna unguiculata (L.) Walp.) is the legume crop. This crop attracted immense importance in cultivation by virtue of it is nitrogen-fixing properties, which fixes $60-70 \mathrm{~kg}$ nitrogen per hectare area, high protein content ranging from $20-25 \%$ in various cultivars and livestock feed as well (Diouf and Hilu, 2005; Sharmar et al. 2013). Compared to other food legumes, cowpea thrives well in drier parts of tropics, hence, established as warm weather and drought-tolerant crop. Due to its shade tolerance, it better fits as an intercrop also (Singh et al., 2003).

Cowpea, though predominantly a pulse crop, initially it's utilized as an underutilized leafy vegetable. In Asia, selection pressure among the introduced unguiculata lines in the process of domestication resulted in the evolution of fleshy, succulent and long pod types. Thus, length of the pod and succulence are the distinguishing features

Corresponding author: Dr. Pidigam Saidaiah Associate Professor, Department of Genetics and Plant Breeding, College of Horticulture, Sri Konda Laxman Telangana State Horticultural University, Mojerla-509 382, Telangana, India E-mail: saidu_genetics@yahoo.co.in; drpidigam@gmail.com Tel.: +91-7780509322

Copyright (C) 2021 Ukaaz Publications. All rights reserved.

Email: ukaaz@yahoo.com; Website: www.ukaazpublications.com of cowpea for the vegetable purpose from traditional cowpea (Smart, 1990; Steele and Mehra, 1980). Common cowpea and or African cowpea are generally grain-type (unguiculata), 'yardlong' bean or asparagus bean is vegetable cowpea (Vigna unguiculata ssp. sesquipedalis). In addition to end-use, thickness and size of the pod and architecture of the plant are the basis for differentiation of two subspecies, at present understanding (Xu et al., 2016, 2010; Timko et al., 2007). The recent investigations revealed further that the cowpea is an excellent vegetable as its tender beans retain a good amount of protein in addition to fibre and other nutrients. To extend the cultivated area, the availability of high yielding varieties, in addition to their biotic and abiotic stress resistance should be ensured.

Several statistical tools, principal component analysis and euclidean clustering as well are employed to study genetic diversity. The PCA technique (Abdi and Williams, 2010) is widely used to assess genetic diversity. Through principal components, this technique helps in maximizing the variance (Jolliffe and Cadima, 2016) and also directs to establish quantitative characters contributing towards genetic divergence (Jindal et al., 2018). Previous studies on divergence in various vegetable crops including cowpea (Kouam et al., 2018 in cowpea, Pidigam et al., 2019 in yard long bean.) highlighted the importance of PCA. The present investigation, therefore, was aimed 
to unravel the genetic divergence among indigenous versus exotic cowpea germplasm based on principal component analysis.

\section{Material and Methods}

An investigation was performed during Kharif, 2019 at College of Horticulture, Sri Konda Laxman Telangana State Horticultural University, Hyderabad, Telangana (India). A total of 87 vegetable cowpea accessions with the inclusion of 59 exotic collections from the International Institute of Tropical Agriculture, Nigeria, along with 24 indigenous germplasm augmented from different states of India and four commercial varieties were evaluated in Randomized Block Design with two replicates. The general packages of practices as recommended were adapted to grow the healthy cowpea crop. Observations were noted with respect to two flowering, two maturities, and six yield attributing traits. The yield per plant and its associate characters were recorded on a plot basis.

\subsection{Statistical analysis}

WINDOSTAT Software Version 9.2. was used for data analysis. Analysis of variance (ANOVA) was taken us to identification significant variations among the genotypes. Principal component analysis and cluster analysis were performed following chord distance coefficient, while the average-linkage method of the datasets were as explained by Mazzucato et al. (2008).

\section{Results}

\subsection{Analysis of variance (ANOVA)}

The values of mean sum of square were significant $(p<0.05)$ for the 87 genotypes based on the ten characters (Table 1), indicating that there is the presence of exercisable and sufficient variation among cowpea accessions under investigation.

Table 1: Analysis of variance of ten key traits in vegetable cowpea genotypes

\begin{tabular}{|l|l|l|l|}
\hline $\begin{array}{l}\text { Source of } \\
\text { Variation }\end{array}$ & $\begin{array}{l}\text { Degrees of } \\
\text { freedom }\end{array}$ & $\begin{array}{l}\text { Sum of } \\
\text { squares }\end{array}$ & $\begin{array}{l}\text { Mean } \\
\text { squares }\end{array}$ \\
\hline Germplasm & 86 & $3.62 \mathrm{E}+16$ & $4.21 \mathrm{E}+14 * *$ \\
\hline Error & 85 & $1.97 \mathrm{E}-02$ & $2.32 \mathrm{E}-04$ \\
\hline Total & 171 & $3.62 \mathrm{E}+16$ & $2.12 \mathrm{E}+14$ \\
\hline
\end{tabular}

Table 2: Principal component analysis of ten key traits in vegetable cowpea genotypes

\begin{tabular}{|l|l|l|l|l|}
\hline Canonical roots analysis (P.C.A) & 1 Vector & 2 Vector & 3 Vector & 4 Vector \\
\hline Eigen Value (Root) & 4.684 & 2.840 & 1.563 & 0.498 \\
\hline \%Var. Exp. & 46.838 & 28.401 & 15.627 & 4.978 \\
\hline Cum. Var. Exp. & 46.838 & 75.240 & 90.866 & 95.844 \\
\hline Eigen vector: Variables & & & & \\
\hline First flowering (days) & 0.417 & 0.152 & 0.230 & 0.046 \\
\hline 50\% flowering (days) & 0.420 & 0.159 & 0.213 & 0.073 \\
\hline 1st fruit set (days) & 0.415 & 0.174 & 0.210 & 0.028 \\
\hline 1st harvest (maturity) (days) & 0.420 & 0.158 & 0.206 & 0.052 \\
\hline Pod length in cm & -0.243 & 0.444 & 0.171 & 0.097 \\
\hline Pod width in cm & -0.243 & 0.428 & 0.164 & -0.468 \\
\hline Mature pod weight in grams & -0.279 & 0.428 & 0.202 & 0.190 \\
\hline Number of pods & -0.161 & -0.206 & 0.633 & -0.482 \\
\hline Number of seeds per pod & -0.018 & 0.521 & -0.344 & 0.078 \\
\hline Pod yield per plant in grams & -0.282 & -0.137 & 0.446 & 0.697 \\
\hline
\end{tabular}

Analysis based on principal component (PC) revealed that three PCs, out of four generated, serially, I PC, II PC and III PC, had eigen values more than one (ranging from 1.56 to 4.68). Three PCs cumulatively contributed to $90.87 \%$ of total variability accounted among accessions studied (Table 2). The PC-I contributed the highest (46.34\%) followed by PC-II with $28.40 \%$, while PC-III contributed for $15.63 \%$ towards variability. The first PC exhibited factor loadings with +ve sign for first flowering days, $50 \%$ flowering days, days taken for setting of first pod and number of days registered to first harvest, while all the factors except for pods set per plant and average pod yield obtained per single plant registered positive factor loading towards PC-II. Towards PC-III, out of ten traits studied, nine traits except for seeds formed per pod have contributed factor loadings in positive sign.
Cluster analysis of genotypes was performed on the basis of ten characters using Tocher's method (Rao, 1952) adapting the $\mathrm{D}^{2}$ statistic (Mahalanobis's, 1936) and is presented in Table 3. Cluster analysis grouped 87 vegetable cowpea genotypes into 16 clusters. Cluster-II comprised of 45 genotypes followed by I and XII clusters, with 22 and 3 genotypes, respectively. While, three clusters, i.e., cluster VIII, XIII and XVI had two genotypes each. Very interestingly, a large number of clusters (III (EC-390225), IV (EC-390230), V (IC-20645), VI(EC-724547), VII (EC-390231), IX (EC-390264), X (EC-715197), XI (IC-249141), XIV (EC-723987) and XV (EC-390239) were solitary with single genotypes.

With reference to cluster means, the lowest cluster mean values and highest cluster mean values (Table 4) were reported in cluster 7 with 
37 days and cluster 10 with 61 days, respectively for first flowering, while cluster 6 and 7 (41.50 days) with early 50\% flowering and cluster 10 (69.50 days) had taken more average days to $50 \%$ flowering. With respect to days to $1^{\text {st }}$ pod set, cluster 7 exhibited an average early pod set (44.50), while the late mean fruit set was exhibited by cluster 10. Cluster 7 and 10 were registered with the lowest average days (50.50) and highest (81) average days to first harvest, respectively.

Table 3: Grouping of genotypes into different clusters in vegetable cowpea

\begin{tabular}{|c|c|c|}
\hline $\begin{array}{l}\text { Cluster } \\
\text { number }\end{array}$ & Number of genotypes & Genotypes \\
\hline 1. & $22(13 \mathrm{EC}$ and $9 \mathrm{IC})$ & $\begin{array}{l}\text { EC-244018, EC-367694, EC-390204, EC-390207, EC-424872, EC-723784, EC-724296, EC- } \\
\text { 724319, EC-724416, EC-724552, EC-724805, EC-724907, EC-738119, IC-202796, IC-202824, } \\
\text { IC-202924, IC-202931, IC-20720, IC-257449, IC-2574563, IC-259063, IC-97806 }\end{array}$ \\
\hline 2. & 45 (36 EC and 9 IC) & $\begin{array}{l}\text { EC-101994, EC-343457, EC-390223, EC-723840, EC-390219, EC-724390, EC-724391, EC- } \\
\text { 724791, EC-734326, EC-390266, EC-724418, IC-202813, EC-367692, EC-724712, EC-72477, } \\
\text { EC-738091, IC-219481, EC-202799, EC-202825, EC-202925, IC-257427, IC-333106, IC- } \\
\text { 91458, IC-202100, IC-202718, IC-202762, EC-725119, EC-725153, EC-725159, EC-725167, } \\
\text { EC-734326, EC-738089, EC-724873, EC-724897, EC-724591, EC-724678, EC-724452, EC- } \\
724471, \text { EC-724484, EC-724328, EC-724364, EC-390269, EC-390278, EC-390233, EC-390239 }\end{array}$ \\
\hline 3 & $1 \mathrm{EC}$ & EC-390225 \\
\hline 4 & $1 \mathrm{EC}$ & EC-390230 \\
\hline 5 & $1 \mathrm{IC}$ & IC-20645 \\
\hline 6 & $1 \mathrm{EC}$ & EC-724547 \\
\hline 7 & $1 \mathrm{EC}$ & EC-390231 \\
\hline 8 & 2 Check varieties & Kashi Kanchan, Kashi Unnati \\
\hline 9 & $1 \mathrm{EC}$ & EC-390264 \\
\hline 10 & $1 \mathrm{EC}$ & EC-715197 \\
\hline 11 & $1 \mathrm{IC}$ & IC-249141 \\
\hline 12 & $4 \mathrm{IC}$ & IC-202827, IC-206240, IC-202931, IC-259069 \\
\hline 13 & 2 Check varieties & Arka Samruddi, Arka Suman \\
\hline 14 & $1 \mathrm{EC}$ & EC-723987 \\
\hline 15 & $1 \mathrm{EC}$ & EC-390239 \\
\hline 16 & $2 \mathrm{EC}$ & EC-390210, EC-724374 \\
\hline
\end{tabular}

Table 4: Cluster means of various characters in vegetable cowpea germplasm

\begin{tabular}{|c|c|c|c|c|c|c|c|c|c|c|}
\hline $\begin{array}{l}\text { Character/ } \\
\text { Cluster }\end{array}$ & $\begin{array}{l}\text { Days to } \\
\text { first } \\
\text { flowering }\end{array}$ & $\begin{array}{l}\text { Days to } 50 \% \\
\text { flowering }\end{array}$ & $\begin{array}{l}\text { Days to } \\
\text { 1st pod } \\
\text { set }\end{array}$ & $\begin{array}{l}\text { Days to } \\
\text { 1st } \\
\text { harvest } \\
\text { (maturity) }\end{array}$ & $\begin{array}{l}\text { Pod } \\
\text { length } \\
(\mathrm{cm})\end{array}$ & $\begin{array}{l}\text { Pod } \\
\text { width } \\
\text { (cm) }\end{array}$ & $\begin{array}{l}\text { Mature } \\
\text { pod } \\
\text { weight } \\
\text { (gm) }\end{array}$ & $\begin{array}{l}\text { No.of } \\
\text { Pods }\end{array}$ & $\begin{array}{l}\text { No.of } \\
\text { seeds } \\
\text { per } \\
\text { pod }\end{array}$ & $\begin{array}{l}\text { Pod } \\
\text { yield } \\
\text { per } \\
\text { plant }(g)\end{array}$ \\
\hline Cluster 1 & 47.32 & 51.27 & 56.14 & 62.14 & 14.55 & 0.60 & 4.04 & 49.72 & 15.41 & 195.17 \\
\hline Cluster 2 & 52.26 & 56.38 & 62.32 & 67.74 & 14.73 & 0.45 & 4.36 & 14.70 & 13.83 & 68.03 \\
\hline Cluster 3 & 40.00 & 43.50 & 47.00 & 54.50 & 17.60 & 1.00 & 7.76 & 29.85 & 17.00 & 249.68 \\
\hline Cluster 4 & 43.00 & 49.00 & 53.50 & 59.00 & 12.75 & 1.00 & 3.68 & 71.13 & 15.50 & 262.56 \\
\hline Cluster 5 & 39.00 & 42.00 & 47.50 & 54.00 & 15.75 & 0.55 & 4.38 & 74.50 & 16.00 & 311.60 \\
\hline Cluster 6 & 39.50 & 44.50 & 47.50 & 52.00 & 15.25 & 0.50 & 3.31 & 1.42 & 10.00 & 4.26 \\
\hline Cluster 7 & 37.00 & 41.50 & 44.50 & 50.50 & 19.60 & 1.10 & 9.18 & 12.63 & 13.50 & 118.13 \\
\hline Cluster 8 & 50.25 & 49.75 & 57.00 & 60.75 & 20.63 & 0.64 & 9.33 & 61.75 & 22.25 & 286.50 \\
\hline Cluster 9 & 49.00 & 54.00 & 61.50 & 67.00 & 19.50 & 0.15 & 8.26 & 52.25 & 14.00 & 428.75 \\
\hline Cluster 10 & 61.00 & 69.50 & 74.50 & 81.00 & 15.25 & 0.50 & 2.66 & 32.13 & 15.50 & 85.10 \\
\hline Cluster 11 & 39.00 & 43.00 & 47.00 & 53.00 & 12.20 & 0.45 & 3.33 & 87.00 & 15.50 & 273.91 \\
\hline Cluster 12 & 55.13 & 57.88 & 64.13 & 70.13 & 14.19 & 0.64 & 3.44 & 108.09 & 15.75 & 367.15 \\
\hline Cluster 13 & 38.25 & 44.50 & 50.00 & 54.50 & 40.75 & 0.75 & 18.50 & 55.25 & 40.75 & 299.00 \\
\hline Cluster 14 & 40.00 & 44.50 & 47.50 & 52.50 & 18.85 & 1.05 & 9.05 & 54.38 & 16.50 & 497.45 \\
\hline Cluster 15 & 39.00 & 44.00 & 47.00 & 51.50 & 17.75 & 0.50 & 5.36 & 90.25 & 16.50 & 490.00 \\
\hline Cluster 16 & 47.00 & 51.25 & 57.25 & 61.50 & 15.38 & 0.75 & 5.46 & 134.63 & 14.75 & 743.65 \\
\hline
\end{tabular}


Average pod length of $40.75 \mathrm{~cm}$ was exhibited by the genotypes of cluster 13, while the lowest was in cluster $11(12.20 \mathrm{~cm})$. For pod width, cluster 7 with $1.1 \mathrm{~cm}$ pod width was the highest cluster mean, while, two clusters, i.e., cluster 2 and cluster 11 exhibited lowest cluster means $(0.45 \mathrm{~cm})$. Cluster 13 had the highest average cluster mean for mature pod weight $(18.50 \mathrm{~g})$ and the number of seeds per pod (40.75). Cluster 16 had exhibited the highest mean cluster values for pods formed per plant (134.63) and pod yield obtained per plant (743.63 g), respectively. While the lowest cluster means were recorded for cluster 6 for the number of pods (1.42), the number of seeds per pod $(10)$ and pod yield per plant $(4.26 \mathrm{~g})$. For pod width $(\mathrm{cm})$, the lowest cluster mean was reported with cluster 10 (2.66) (Table 4). Pair-wise Mahalanobis cluster distances ( $\mathrm{D}^{2}$ statistics) are presented in Table 5. Based on inter cluster distances, the maximum diversity of 46082.81 was elucidated between cluster VI and XVI followed by cluster 7 and 16 (40581.15), while lowest inter cluster distance was noticed between cluster-IV and cluster-V (215.49). The intra cluster distances revealed that cluster 12 was most diverse with a distance of 1178.37 followed by cluster 16 (1178.33) and cluster 2 (931.14). While, intra cluster distances of 780.62, 595.56 and 343.54 were reported for cluster 1 , cluster 13 and cluster 8 , respectively. Ten out of 16 clusters had zero intra cluster distances.

Table 5: Cluster distances (inter and intra) in vegetable cowpea accessions

\begin{tabular}{|c|c|c|c|c|c|c|c|c|}
\hline Cluster number & Cluster 1 & Cluster 2 & Cluster 3 & Cluster 4 & Cluster 5 & Cluster 6 & Cluster 7 & Cluster 8 \\
\hline Cluster 1 & 780.62 & 3864.55 & 2254.89 & 1601.78 & 1995.58 & 6414.46 & 5182.63 & 6128.01 \\
\hline Cluster 2 & 3864.55 & 931.14 & 1888.49 & 8535.52 & 9412.33 & 1559.45 & 1834.74 & 11589.43 \\
\hline Cluster 3 & 2254.89 & 1888.49 & 0.00 & 5385.12 & 5475.73 & 2356.28 & 917.97 & 7660.89 \\
\hline Cluster 4 & 1601.78 & 8535.52 & 5385.12 & 0.00 & 215.49 & 12343.13 & 10172.83 & 4999.14 \\
\hline Cluster 5 & 1995.58 & 9412.33 & 5475.73 & 215.49 & 0.00 & 12864.40 & 10385.13 & 5962.39 \\
\hline Cluster 6 & 6414.46 & 1559.45 & 2356.28 & 12343.13 & 12864.40 & 0.00 & 837.86 & 15480.14 \\
\hline Cluster 7 & 5182.63 & 1834.74 & 917.97 & 10172.83 & 10385.13 & 837.86 & 0.00 & 11317.07 \\
\hline Cluster 8 & 6128.01 & 11589.43 & 7660.89 & 4999.14 & 5962.39 & 15480.14 & 11317.07 & 343.54 \\
\hline Cluster 9 & 1287.24 & 4641.96 & 2041.81 & 2119.60 & 2152.63 & 7684.54 & 5360.01 & 6157.38 \\
\hline Cluster 10 & 2024.60 & 1960.55 & 3142.69 & 4762.65 & 6069.29 & 4953.14 & 4951.18 & 8274.75 \\
\hline Cluster 11 & 3917.05 & 13523.60 & 9245.17 & 709.69 & 537.30 & 17806.47 & 15225.82 & 7531.51 \\
\hline Cluster 12 & 9785.01 & 22802.75 & 18431.00 & 4339.73 & 4545.21 & 30019.63 & 26656.64 & 11372.52 \\
\hline Cluster 13 & 14659.41 & 18034.93 & 12778.56 & 14880.85 & 15590.86 & 21097.42 & 14916.65 & 3902.30 \\
\hline Cluster 14 & 2077.85 & 6083.99 & 1909.79 & 2501.89 & 2137.00 & 8239.79 & 5216.79 & 5489.34 \\
\hline Cluster 15 & 4904.38 & 15142.90 & 9624.34 & 1395.32 & 847.14 & 19656.51 & 16089.06 & 7575.34 \\
\hline Cluster 16 & 19794.90 & 37696.84 & 29789.93 & 11395.65 & 10693.70 & 46082.81 & 40581.15 & 19165.89 \\
\hline Cluster number & Cluster 9 & Cluster 10 & Cluster 11 & Cluster 12 & Cluster 13 & Cluster 14 & Cluster 15 & Cluster 16 \\
\hline Cluster 1 & 1287.24 & 2024.60 & 3917.05 & 9785.01 & 14659.41 & 2077.85 & 4904.38 & 19794.90 \\
\hline Cluster 2 & 4641.96 & 1960.55 & 13523.60 & 22802.75 & 18034.93 & 6083.99 & 15142.90 & 37696.84 \\
\hline Cluster 3 & 2041.81 & 3142.69 & 9245.17 & 18431.00 & 12778.56 & 1909.79 & 9624.34 & 29789.93 \\
\hline Cluster 4 & 2119.60 & 4762.65 & 709.69 & 4339.73 & 14880.85 & 2501.89 & 1395.32 & 11395.65 \\
\hline Cluster 5 & 2152.63 & 6069.29 & 537.30 & 4545.21 & 15590.86 & 2137.00 & 847.14 & 10693.70 \\
\hline Cluster 6 & 7684.54 & 4953.14 & 17806.47 & 30019.63 & 21097.42 & 8239.79 & 19656.51 & 46082.81 \\
\hline Cluster 7 & 5360.01 & 4951.18 & 15225.82 & 26656.64 & 14916.65 & 5216.79 & 16089.06 & 40581.15 \\
\hline Cluster 8 & 6157.38 & 8274.75 & 7531.51 & 11372.52 & 3902.30 & 5489.34 & 7575.34 & 19165.89 \\
\hline Cluster 9 & 0.00 & 2964.23 & 4561.51 & 9921.47 & 13514.84 & 652.89 & 4184.23 & 18064.80 \\
\hline Cluster 10 & 2964.23 & 0.00 & 8775.75 & 14617.45 & 16658.06 & 5301.19 & 10546.70 & 28165.05 \\
\hline Cluster 11 & 4561.51 & 8775.75 & 0.00 & 2557.30 & 18787.04 & 4630.71 & 606.74 & 7618.13 \\
\hline Cluster 12 & 9921.47 & 14617.45 & 2557.30 & 1178.37 & 24395.98 & 11028.86 & 2864.20 & 3763.37 \\
\hline Cluster 13 & 13514.84 & 16658.06 & 18787.04 & 24395.98 & 595.86 & 11700.35 & 17746.82 & 32796.37 \\
\hline Cluster 14 & 652.89 & 5301.19 & 4630.71 & 11028.86 & 11700.35 & 0.00 & 3758.11 & 17846.79 \\
\hline Cluster 15 & 4184.23 & 10546.70 & 606.74 & 2864.20 & 17746.82 & 3758.11 & 0.00 & 5956.56 \\
\hline Cluster 16 & 18064.80 & 28165.05 & 7618.13 & 3763.37 & 32796.37 & 17846.79 & 5956.56 & 1178.33 \\
\hline
\end{tabular}


From per cent contribution to total divergence, it is evident that pod number per plant contributed maximum $(72.89 \%)$, which ranked 2727 times followed with days taken to $50 \%$ flowering $(8.29 \%)$, pod width $(5.99 \%)$, mature pod weight $(4.04 \%)$, per plant pod yield $(3.77 \%)$ and number of days genotypes took to first pod set $(3.50 \%)$ for total genetic divergence reported. While negligible $(<1 \%)$ contribution was made by days to 1 st harvest, pod length and number of seeds per pod. Days to first flowering had no contribution (zero times ranked 1st) towards total genetic divergence in the present study (Table 6).

Table 6: Per cent contribution of various characters towards total divergence in vegetable cowpea germplasm

\begin{tabular}{|l|l|l|}
\hline Source & $\begin{array}{l}\text { Number of times } \\
\text { Ranked 1 }\end{array}$ & $\begin{array}{l}\text { Contribution } \\
\text { in per cent }\end{array}$ \\
\hline First flowering (days) & 0 & $0 \%$ \\
\hline 50\% flowering (days) & 310 & $8.29 \%$ \\
\hline Days to 1st fruit set & 131 & $3.50 \%$ \\
\hline $\begin{array}{l}\text { Days to 1st harvest } \\
\text { (maturity) }\end{array}$ & 32 & $0.86 \%$ \\
\hline Pod length (cm) & 13 & $0.35 \%$ \\
\hline Pod width (cm) & 224 & $5.99 \%$ \\
\hline Mature pod weight (gm) & 151 & $4.04 \%$ \\
\hline No. of pods per plant & 2727 & $72.89 \%$ \\
\hline No. of seeds per pod & 12 & $0.32 \%$ \\
\hline Pod yield per plant (g) & 141 & $3.77 \%$ \\
\hline
\end{tabular}

\section{Discussion}

From the analysis of variance, the significance of germplasm studied for the ten characters indicated that there is the presence of exercisable and sufficient variation among cowpea accessions under investigation. Genetic variation is the pre-requisite for any crop improvement. Hence, the 87 genotypes investigated can act as the basis for further selection of high yielding vegetable cowpea varieties. More so, the exotic germplasm introduced from IITA, Negeria will further broaden the germplasm pool of Indian vegetable cowpea, if included in crossing programmes. Thangam (2020) and Fatokun et al. (2017) studied genetic divergence in cowpea and found high divergence.

Based on principle component analysis, three PCs out of four, viz., I PC, II PC and III PC, cumulatively contributed more than $90 \%$ of total variability, explaining they are the reliable for revealing variability. It is observed that vegetable cowpea flowering (DFF, D50\% F) and maturity (DFFS, DFFH) related traits were those with highest contribution to PC-I, whereas pod related traits, number of seeds per pod, pod length, mature pod weight and pod width were the major contributors to II PC. Hence, both I PC and II PC could be named, collectively as a reproductive axis. The PC-III, therefore, can act as the vegetative axis, as the number of pods presented in it contributed maximum share. The study clearly highlighted that principal component (s) analysis is useful for identification of some traits, which can act as basis for executing selections. The similar findings are reported earlier by several investigators (Krasteva and Dimova, 2007; Usha Kumari et al., 2000; Fang et al., 2007; Aremu et al., 2007; Walle et al., 2019). Fatokun et al. (2017) reported $22.30 \%$ of variation in cowpea with the two principal components. As many as 115 accessions were included in a single cluster. Recently, Nkhoma et al. (2020) evaluated 100 cowpea genotypes and reported wider diversity. The investigation also gave clue that based on the values of principal component analysis, the multivariate analysis aids to place accessions in appropriate clusters.

Cluster analysis grouped 87 vegetable cowpea genotypes into 16 clusters revealing the greater amount of genetic diversity among the germplasm. With 45 genotypes cluster-II was the largest followed by I (22 genotypes) and XIII (4 genotypes) clusters. It is understood that the selection of one or the other genotype from the same cluster would yield similar heterosis. EC-390225, EC-390230, IC-20645, EC-724547, EC-390231, EC-390264, EC-715197, IC-249141, EC723987 and EC-390239 were the single genotypes placed in different clusters unraveling maximum diversity possessed with them. These genotypes upon crossing among each other may lead pooling of versatile genes into single cultivar by adopting pedigree breeding. The four check varieties were grouped into two clusters, i.e., cluster 8 (Kashi Kanchan, Kashi Unnati) and 13 (Arka Samruddi, Arka Suman), the directional selection for the commercial yield might have contributed to their similarity. Kashi Kanchan and Kashi Unnati are the varieties released for commercial cultivation from the Indian Institute of Vegetable Research, Varanasi. And similarly, from the Indian Institute of Horticulture Research, Bengaluru; Arka Samruddi, Arka Suman were released for cultivation, which has shared the pedigree. So, the study clearly grouped the genotypes based on the centre of origin. This is further evidenced by the grouping of four indigenous collections, IC-202827, IC-206240, IC-202931 and IC259069 into cluster 12 and two exotic collections, EC-390210 and EC-724374 into cluster 16 . The solitary clusters were dominated by EC lines by 80 per cent compared to IC lines ( 20 per cent). Overall clustering showed that EC lines were more divergent as they were present in 11 clusters versus indigenous clusters, which were grouped into only 4 clusters. However, the grouping of exotic and indigenous lines together into a single cluster indicates that there is no relation between the centre of origin and the centre of diversity. Genetic diversity estimates among lines/accessions is propellant in the improvement and selection of better varieties (Carvalho et al., 2020). Carvalho et al. (2020) reported that the accessions of Iberian Peninsula were characterized with little genetic diversity as compared to those of worldwide. Similarly, (Lal et al., 2017; Saini et al., 2004 in cowpea; Pidigam et al., 2019) in yardlong bean and Saidaiah et al. (2021) in jack bean also stressed the importance of genetic diversity for breeding new varieties. The improved diverse varieties always have an edge over local cowpea varieties (Manda et al., 2019). From the investigation, very unique genotypes were identified with respect to yield both in exotic and indigenous accessions. Hence, the identified genetically distant genotypes are used in the hybridization programme to further isolate new improved vegetable cowpea varieties.

Varieties with early flowering and maturity are well fit in cropping systems due to their shortest crop duration based on cluster means. EC-390231 of cluster 7 had registered lowest cluster mean value of 37 days was to first flowering and along with EC-724547 of cluster 6 taken 41.50 days for $50 \%$ flowering. EC-390231 also early to days to $1^{\text {st }}$ fruit set $(44.50)$ and average days to the first harvest (50.50). The identified genotype could be explored further for breeding early vegetable cowpea varieties in India. As such, multilocation trials of this genotype could also result in establish stability for its 
earliness. Two genotypes, viz., Arka Samruddi and Arka Suman of cluster 13 had average pod length $(40.75 \mathrm{~cm})$ and with $1.1 \mathrm{~cm}$ pod width, were the highest. In addition, the same genotypes had the highest average cluster mean for mature pod weight $(18.50 \mathrm{~g})$ and the number of seeds per pod (40.75). The vegetable cowpea clearly differentiated from grain cowpea due to its pod length and width. The cowpea types released for vegetable purpose in India had pod lengths minimum of $25 \mathrm{cms}$ to $50 \mathrm{~cm}$ (Pidigam et al., 2019 and Rambabu et al., 2017). The pod length is also main attribute of per plant green pod yield. There is potential for commercial release of those varieties with maximum length. EC-390210 and EC-724374 of cluster 16 had exhibited the highest mean cluster values for green pods formed per plant (134.63) and pod yield obtained per plant (743.63 g), respectively. Economic yield is ultimate objective of any crop breeding programme. In view of the highest average yield realized with EC-390210 and EC-724374 among all the genotypes in investigation. They hold promise for out yield, if tested across seasons and locations as well. These are the EC lines from Nigeria, may exhibit even biotic and abiotic stress resistance with proper plan and execution. The farmers can have wider choice of commercial varieties in vegetable cowpea in India. Nancee et al. (2013) concluded that the vegetable cowpea genotypes of cluster II followed by cluster I and V performed better for certain agronomic characters.

The Mahalanobis cluster distances depicted maximum genetic diversity between cluster VI and XVI followed by cluster VII and $\mathrm{XVI}$. To achieve maximum heterosis, a crossing programme needs to be planned between EC-724547 (Cluster VI) with EC-390210 or EC724374 (Cluster XVI). Similarly, transgressive segregants could be expected in pedigree breeding method of handling of EC-390231 with the genotypes of cluster XVI (EC-390210 or EC-724374). The little inter cluster distance noticed between cluster-IV and cluster-V warrants that poor genetic diversity associated with EC-390210 and IC-20645. Based on the intra cluster distances, the cluster 12 followed by cluster 16 had 4 indigenous collections and 2 exotic collections, respectively. Both these clusters though having less number of genotypes, the variation among the accessions present in clusters were higher in comparison with rest of the 14 clusters genotypes. Interestingly, cluster 2 and cluster 1 had less intra cluster distances in spite possessing 45 and 22 genotypes, respectively. This is possible when the genetic diversity among the genotypes of the clusters is meager and genotypes might share the same pedigree. Presence of solitary genotypes was the reason for ten clusters (Cluster $3,4,5,6,7,9,10,11,14$ and 15) with zero intra cluster distances. The study established that cluster analysis is regarded as powerful tool to group germplasm, which can act as reliable basis to select material planning breeding strategies. The earlier studies by Patel $e t$ al. (2017) confirmed the present results. However, several clusters had EC lines in the study. Hence, one must be vigilant of genetic barriers and appropriate breeding strategy to get anticipated improvement of the targeted character.

The pod number per plant followed with days taken to $50 \%$ flowering and pod width contributed maximum towards total genetic divergence reported in the study, as pictured from per cent contribution of traits. It implies that 87 genotypes were genetically more variable for pod number per plant and flowering of 50 per cent of plants. Thus, the present study recommends that the genotypes can be selected based on pods set per plant followed by days taken to reach $50 \%$ of plants to flowering, which were with maximum contribution for total divergence of the germplasm under investigation. While, days to first flowering had no contribution followed by negligible $(<1 \%)$ contribution by days to 1 st harvest, pod length and number of seeds per pod towards total genetic divergence in the present study. This indicates the performance of accessions studied for these characters is at par and they do not serve as the basic material for further selections. Certain earlier (Patel et al., 2017; Lal et al., 2017) studies reported similar trend of results. Nancee et al. (2013) reported that seeds per pod followed by plant stature registered maximum contribution towards total divergence in vegetable cowpea.

\section{Conclusion}

It is to conclude that based on principal component analysis and cluster analysis, exotic and indigenous genotypes have greater diversity as there were 16 clusters, which was further confirmed by Mahalanobis $\mathrm{D}^{2}$ statistic, which elucidated maximum diversity among the genotypes between clusters. Therefore, the investigation suggests that hybrid combinations between exotic collections (EC-724547, EC-390210, EC-724374, EC-390231, and EC-724374) of genetically diverse clusters could be considered to execute maximum heterosis in hybrid breeding and isolating superior segregant lines useful for vegetable cowpea breeding.

\section{Funding}

The present research did not receive any specific grant from funding agencies in the public, commercial, or not-for-profit sectors.

\section{Acknowledgments}

The authors thank Dr. Lingaiah Nelagondarasi, Associate Professor of Genetics and Plant Breeding, College of Agriculture, Professor Jayashankar Telangana State Agricultural University, Warangal, Nagarkurnool Dist., Telangana, India for help in statistical analysis of data and generating graphs.

\section{Conflicts of interest}

The authors declare that there are no conflicts of interest relevant to this article.

\section{References}

Abdi, H. and Williams, L.J. (2010). Principal component analysis. Wiley interdisciplinary reviews: Computational Statistics, 2(4):433-459.

Ahmad, I.; Basra, S.M.A. and Wahid, A. (2014). Exogenous application of ascorbic acid, salicylic acid and hydrogen peroxide improves the productivity of hybrid maize under at low temperature stress. Int. J. Agric. Biol., 16:825-830.

Aremu, M.O.; Olaofe, O. and Akintayo, E.T. (2007). Functional properties of some Nigerian varieties of legume seed flours and flour concentration effect on foaming and gelation properties. J. Food Technol., 5(2): 109-1 15

Carvalho, M.; María, M.A.; Isaura, C.;Teresa, L.N.; Manuela, M.; Marcos, E.C.; Eduardo, R.; Timothy, C. and Valdemar, C. (2020). Genetic diversity and structure of Iberian Peninsula cowpeas compared to worldwide cowpea accessions using high-density SNP markers. BMC Genomics. 118:891. https://doi.org/10.1186/s12864-017-4295.

Krasteva, L. and Dimova, D. (2007). Evaluation of a large-fruited determinate tomato collection using cluster analysis and principal component analysis (PCA). Acta Hortic., 729:85-88. https://doi.org/10.17660/ ActaHortic.2007.729.11 
Diouf, D. and Hilu, K.W. (2005). Microsatellites and RAPD markers to study genetic relationships among cowpea breeding lines and local varieties in Senegal. Genet. Resour. Crop Evol., 52:1057-1067. https://doi.org/10.1007/s10722-004-6107-z.

Fang, J.; Chao, C.C.T.; Roberts, P.A. and Ehlers, J.D. (2007). Genetic diversity of cowpea (Vigna unguiculata (L.) Walp.) in four West African and USA breeding programs as determined by AFLP analysis. Genet. Resour., Crop Evol., 54:1197-1209.

Fatokun, C.; Gezahegn, G.; Michael, A.; Melaku, G.; Nnanna, U.; Olaniyi, O.; Muyideen, Y.; Ismail, R. and Ousmane, B. (2017). Genetic diversity and population structure of a mini-core subset from the world cowpea (Vigna unguiculata (L.) Walp.) germplasm collection. Sci. Rep., https://doi.org/10.1038/s41598-018-34555-9.

Jindal, Y.; Rajesh, Y. and Phogat, D.S. (2018). Principal component analysis and determination of the selection criteria in fodder cowpea (Vigna unguiculata (L) Walp.) genotypes. Range Manag. Agrofor., 39(2):191-196.

Jolliffe, I.T. and Jorge, C. (2016). Principal component analysis: a review and recent developments. Philosophical Transactions of the Royal Society A: Mathematical, Physical and Engineering Sciences, 374(2065):20150202.

Kouam, E.B.; Ndo, S.M.; Mandou,M.S.; Chotangui,A.H. and Tankou, C.M. (2017) Genotypic variation in tolerance to salinity of common beans cultivated in Western Cameroon as assessed at germination and during early seedling growth. Open Agric., 2:600-610.

Lal, H.; Reddy, B.R. and Nath, V. (2017). Biometrical studies of yield and related traits in advance breeding lines of bush type vegetable cowpea (Vigna unguiculata (L.) Walp.). Legume Res., 40 https://doi.org/ 10.18805/LR3799.

Mahalanobis, P.C. (1936). Proc. Nat. Acad. Sci., India. 2:49-55.

Manda,J; Alene, A.D.; Tufa,A.H.Abdoulaye, T; Wossen, T.; Chikoye, D. and Manyong, V. (2019). The poverty impacts of improved cowpea varieties in Nigeria: A counterfactual analysis. World Dev., 122:261-271. https:/ /doi.org/10.1016/j.worlddev.2019.05.027.

Mazzucato, A.; Papa, R.; Bitocchi, E.; Mosconi, P.; Nanni, L.; Negri, V.; Picarella, M.E.; Siligato, F.; Soressi, G.P.; Tiranti, B. and Veronesi, F. (2008). Genetic diversity, structure and marker trait associations in a collection of Italian tomato (Solanum lycopersicum L.) landraces. Theor. Appl. Genet., 116:657-669.

Nancee, K.; Rana, M. K.; Partap, P.S. and Ranjan, R. (2013). Study of genetic divergence on vegetable cowpea (Vigna unguiculata (L.) Walp.). Vegetable Sci., 40:182-184.

Nkhoma, N.; Shimelis, H.; Laing, M.D. (2020). Assessing the genetic diversity of cowpea (Vigna unguiculata (L.) Walp.) germplasm collections using phenotypic traits and SNP markers. BMC Genet., 21:110. https://doi.org/10.1186/s12863-020-00914-7.

Patel, U.V.; Parmar, V.K.; Tandel, Y.N. and Patel, H.R.(2017). Genetic divergence in cowpea (Vigna unguiculata (L.) Walp.) for yield components parameters. Electronic J. Plant Breed., 8:331-335.

Pidigam, S.; Munnam, S.B. and Nimmarajula, S. (2019). Assessment of genetic diversity in yardlong bean (Vigna unguiculata (L.) Walp subsp. sesquipedalis Verdc.) germplasm from India using RAPD markers. Genet. Resour. Crop Evol., 66:1231-1242. https://doi.org/ 10.1007/s10722-019-00782-w.

Rachie, K.O. (1985). Introduction. In Cowpea: Research, Production and Utilization. Singh, S.R. and K.O. Rachie (Eds). John Wiley.

Rao, C.R. (1952). Advanced statistical methods in biometrical research. John Wiley and Sons, New York. P.390.

Saidaiah, P.; Pandravada, S.R.; Sivaraj, N.; Geetha, A. and Lingaiah, N. (2021). Understanding of yield stability in jack bean (canavalia ensiformis 1.) genotypes using AMMI and GGE bi-plot models. https://doi.org/ 10.18805/LR-4548.

Saini, M.L.; Jain, P. and Arora, R.N. (2004). Genetic divergence studies for quantitative characters in cowpea (Vigna unguiculata (L.) Walp.). Forage Res., 30:152-154.

Sharmar, S.; Upadhyaya, H.D.; Rootkiwal, M.; Varshney, R.K. and Gowda, C.L.L. (2013). In M. Singh, H.D. Upadhyaya, I.S. Bisht (eds). Genetic and Genomic Resources of Grain Legume Improvement, Elsevier, London, UK, pp:81-104.

Singh, B.; Ajeigbe, H.A.; Tarawali, S.A.; Fernandez-Rivera, S. and Abubakar, M. (2003). Improving the production and utilization of cowpea as food and fodder. Field Crops Res., 84:169-150.

Smart, J. (1990). Grain Legumes: Evolution and Genetic Resources. Cambridge University Press, Cambridge. pp:397.

Steele, W.M. and Mehra, K.L. (1980). Structure, evolution and adaptation to farming systems and environment in Vigna. In Advances in Legume Sciences. Summer field, R.J. and A.H. Bunting (Eds). London, pp: 393-404.

Teja, R.R.; Saidaiah, P.; Kumar,A.K.; Geetha,A. and Bhasker, K. (2021). Stability analysis of yield and yield attributing traits of promising genotypes of cluster bean (Cyamopsis Tetragonoloba L. Taub.). Legume Res., https://doi.org/10.18805/LR-4546.

Thangam, M.; Ramachandrudu, K.; Ashok Kumar, J.; Safeena, S.A. and Priya Devi, S. (2020). Variability and genetic divergence in vegetable cowpea germplasm of Goa. J. Hortic. Sci., 15(1):45-51. https://doi.org/ 10.24154/JHS.2020.v15i01.006

Timko, M.P.; Ehlers, J.D. and Roberts, P.A. (2007). Cowpea. In: Kole CM, editor. Genome mapping and molecular breeding in plants: pulses, sugar and tuber crops. New York: Springer-Verlag, pp:49-67.

Usha Kumari, R.; Backiyarani, S. and Dhanakodi, M. (2000). Character contribution to diversity in cowpea. Legume Res., 23:122-125

Walle, T.; Mekbib, F.; Amsalu, B. and Gedil, M. (2019). Genetic Diversity of Ethiopian cowpea (Vigna unguiculata L. Walp) genotypes using multivariate analysis. Ethiop. J. Agric. Sci., 29(3):89-104.

Xu, P.; Wu, X.; Muñoz-Amatriaín, M.; Wang, B.; Wu, X. and Hu, Y. (2016). Genomic regions, cellular components and gene regulatory basis underlying pod length variations in cowpea (V. unguiculata L. Walp). Plant Biotechnol. J., 15:1-11.

Xu, P.; Wu, X.; Wang, B.; Liu, Y.; Qin, D. and Ehlers, J.D.(2010). Development and polymorphism of Vigna unguiculata ssp. unguiculata microsatellite markers used for phylogenetic analysis in asparagus bean (Vigna unguiculata ssp. sesquipedialis (L.) Verdc.). Mol. Breed., 25(4):67584 